\title{
Retinoid X Receptor
}

National Cancer Institute

\section{Source}

National Cancer Institute. RetinoidX Receptor. NCI Thesaurus. Code C17534.

Human nuclear Retinoid X Receptors RXRA, RXRB, and RXRG (NR2/RXR Family) are transcriptional regulators composed of $\mathrm{N}$-terminal modulating domain, DNA-binding domain (AGGT CA response elements), and C-terminal 9-cis RA-binding domain. RXR homodimers and RXR/RAR heterodimers mediate distinct retinoic acid response pathways. RXRs also interact with $\mathrm{TH}$ - and vitamin $\mathrm{D}$ receptors, and with NCOA3, NCOA6, PML, and PPARG coactivators; and mediate RA biological effects by binding to specific target gene promoters and inducing target gene transcription. RXRs/LXRs and RXRs/FXR may mediate cholesterol homeostasis, by governing cholesterol transport from peripheral cells, inhibiting cholesterol absorption in the small intestine, and repressing bile acid synthesis through upregulation of $A B C 1$ and repression of CYP7A1 expression. $(\mathrm{NCl})$ 